\title{
PERBEDAAN HASIL PEMBELAJARAN AKUNTANSI MENGGUNAKAN METODE SNOWBALL THROWING DAN METODE KONVENSIONAL PADA SISWA KELAS XI IPS SMAN ARJASA
}

\author{
Moh. Usman Kurniawan \\ IKIP PGRI Jember \\ usmankurniawan@ikipjember.ac.id
}

\begin{abstract}
ABSTRAK
Penelitian eksperimen ini bertujuan untuk mengetahui perbedaan hasil belajar siswa pada pembelajaran akuntansi dengan menggunakan metode snowball throwing dan metode konvensional. Penelitian ini menggunakan dua kelas pada SMAN Arjasa. Kelas XI IPS 1 terpilih menjadi kelas yang diajar menggunakan metode snowball throwing dan kelas XI IPS 3 terpilih menjadi kelas kontrol atau kelas yang diajarkan dengan menggunakan metode konvensional. Teknik analisis data yang digunakan dalam penelitian ini adalah uji t. Hasil penelitian menunjukkan bahwa skor hasil belajar siswa di kelas eksperimen dengan menggunakan metode snowball throwing pada pembelajaran akuntansi sebelum dan sesudah diberikan perlakuan mengalami peningkatan yang lebih tinggi daripada kelas kontrol yang menggunakan metode konvensional.
\end{abstract}

Kata Kunci: Metode snowball throwing; Metode konvensional; Hasil belajar siswa; Pembelajaran akuntansi.

\begin{abstract}
This experimental research aim is to determine the differences between student learning outcomes in accounting learning by using snowball throwing method and conventional method. This research used two classes on SMAN Arjasa. The class of XI IPS 1 was the class which taught by snowball throwing method and class XI IPS 3 was selected as the control class or class which taught by conventional method. Data analysis technique used in this study was the t-test. The results showed that there was a higher score improvement after giving treatment in the experimental class using the snowball throwing in accounting learning, than the the control class using the conventional method.
\end{abstract}

Keywords: $\quad$ Throwing snowball method; The conventional method; Outcomes learnin;, Accounting learning.

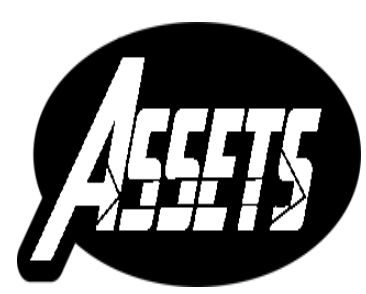

ASSETS:

Jurnal Akuntansi dan Pendidikan Vol. 6 No. 1 Hlmn. 42-58

Madiun, April 2017 p-ISSN: 2302-6251 e-ISSN: 2477-4995

Artikel masuk: 15 Januari 2017 Tanggal diterima: 1 Februari 2017 


\section{PENDAHULUAN}

Pembelajaran merupakan suatu proses interaksi antara siswa dan guru serta sumber belajar pada suatu lingkungan pembelajaran. Tujuan dari suatu pembelajaran adalah meningkatnya hasil belajar siswa dan terdapat perubahan perilaku yang positif pada diri siswa. Hasil belajar merupakan suatu gambaran kemampuan siswa dalam memenuhi suatu tahapan pencapaian pengalaman belajar dalam satu kompetensi dasar (Sanjaya, 2011 : 27). Pembelajaran pada hakikatnya adalah proses interaksi antar peserta didik dengan pendidik dan lingkungannya, sehingga terjadi hasil belajar yang lebih baik (Mulyasa, 2008).

Tugas guru yang paling utama adalah mengkondisikan lingkungan agar menunjang terjadinya perubahan perilaku bagi peserta didik. Belajar juga merupakan proses pencapaian kompetensi, keterampilan dan sikap. Secara keseluruhan, belajar merupakan proses berkesinambungan selama hidup. Hal ini yang dalam dunia pendidikan disebut pendidikan sepanjang hayat (long life education) (Yuliati, 2008). Suprijono (2009) menyatakan bahwa hasil belajar ialah berupa pola-pola perbuatan, nilai-nilai, pengertian-pengertian, sikap-sikap, apresiasi dan ketrampilan, yang meliputi: informasi verbal, kecakapan intelektual, strategi kognitif, kecakapan motorik, dan sikap.

Hasil belajar adalah kemampuan-kemampuan yang dimiliki siswa setelah ia menerima pengalaman belajar, yang wujudnya berupa kemampuan kognitif, afektif, dan psikomotor. Hasil belajar berkaitan dengan pencapaian dalam memperoleh kemampuan sesuai dengan tujuan khusus yang direncanakan. Hasil belajar tampak sebagai terjadinya perubahan tingkah laku pada diri siswa, yang dapat diamati dan diukur dalam bentuk perubahan pengetahuan, sikap dan keterampilan. Hasil belajar yang dilihat dalam penelitian ini adalah ranah kognitif (penguasaan intelektual) berupa nilai hasil belajar dengan menggunakan metode Snowball Throwing dan menggunakan metode konvensional (ceramah). Menurut Lie (2007:5), hasil belajar merupakan perubahan perilaku yang diperoleh pembelajar setelah mengalami aktivitas belajar. Perolehan aspek-aspek perubahan perilaku tersebut tergantung pada apa yang dipelajari oleh pembelajar dalam hal ini adalah siswa.

Pembelajaran yang berorientasi terhadap tujuan pendidikan tentunya sangat diperlukan suatu perencanaan dan persiapan yang matang, baik tentang metode pembelajaran maupun kesiapan guru saat akan melakukan kegiatan pembelajaran. Pemilihan metode yang tepat akan mempermudah siswa untuk menyerap materi pembelajaran. Hal ini dipertegas oleh Arsyad (2011) yang menyatakan bahwa di dalam proses pembelajaran, terdapat dua unsur yang sangat penting, yaitu metode dan media pembelajaran. Kedua aspek tersebut sangat berkaitan. Hal ini karena pemilihan metode pembelajaran akan mempengaruhi jenis media pembelajaran yang sesuai, meskipun masih terdapat berbagai aspek lain yang harus diperhatikan dalam proses pemilihan suatu media pembelajaran. Meskipun demikian, dapat dikatakan bahwa media pembelajaran merupakan alat bantu dalam pembelajaran yang turut serta dalam mempengaruhi kondisi, iklim, dan lingkungan pembelajaran yang diciptakan dan ditata oleh guru.

Metode pembelajaran berarti cara-cara yang dilakukan dalam proses pembelajaran sehingga dapat diperoleh hasil yang optimal. Dengan kata lain, metode pembelajaran juga bisa diartikan sebagai teknik pembelajaran yang akan diterapkan atau dipergunakan pengajar untuk memberikan pengajaran di kelas (Sugihartono, Kartika, Harahap, Farida, dan Siti, 2007). Guru harus mengetahui ruang lingkup metode pembelajaran agar memahami betul dalam penentuan metode pembelajaran. Selain itu, Thoifuri (2007) menyatakan bahwa ruang lingkup dari sebuah metode 
meliputi pengertian metode, jenis-jenis metode, faktor yang terkait dalam pemilihan metode, sejarah lahirnya metode, tujuan metode, kelemahan dan kelebihan metode, cara menanggulangi kelemahan metode, dan cara mengembangkan metode.

Sukir (2009) menyatakan bahwa guru yang berperan sebagai fasilitator di dalam proses pembelajaran harus mampu memilih serta menentukan metode pembelajaran yang tepat dengan materi yang akan diajarkan sehingga diharapkan pembelajaran mampu berjalan secara efektif dan tujuan pembelajaran berhasil dicapai. Akan tetapi, pada kenyatannya kondisi yang sangat diinginkan belum terwujud. Hal ini dikarenakan dalam proses pembelajaran yang dilakukan selama ini di sekolah masih belum memperhatikan keefektivitas dan kesesuaian metode pembelajaran dengan materi yang akan diajarkan serta guru kurang kreatif di dalam menstimulus siswa supaya mampu dalam mengintegrasikan konstruksi pengalaman kehidupannya sehari-hari di luar kelas dengan konstruksi pengetahuannya di dalam kelas.

Pembelajaran dengan metode konvensional ditandai dengan ceramah yang diiringi dengan penjelasan, serta pembagian tugas dan latihan. Sejak dahulu guru dalam usaha menularkan pengetahuannya pada siswa, ialah secara lisan atau ceramah. Pembelajaran konvensional yang dimaksud adalah pembelajaran yang biasa dilakukan oleh para guru. Pembelajaran konvensional (tradisional) pada umumnya memiliki kekhasan tertentu, misalnya lebih mengutamakan hafalan daripada pengertian, menekankan kepada keterampilan berhitung, mengutamakan hasil daripada proses, dan pengajaran berpusat pada guru.

Istilah konvensional mengandung arti apa yang sudah menjadi kebiasaan (tradisional). Menurut Sanjaya (2011: 115) dalam pembelajaran konvensional, siswa ditempatkan sebagai objek belajar yang berperan sebagai penerima informasi secara pasif dengan menerima, mencatat dan menghapal materi pelajaran. Metode pembelajaran konvensional merupakan metode pembelajaran yang berpusat pada guru dan bersifat otoriter yang mencakup pemberian informasi oleh guru, tanya jawab, pemberian tugas oleh guru, pelaksanaan tugas oleh siswa sampai pada akhirnya guru merasa bahwa apa yang telah diajarkan dapat dimengerti oleh siswa (Rasana, 2009). Metode pembelajaran konvensional jarang melibatkan pengaktifan pengetahuan awal dan jarang memotivasi siswa untuk proses pengetahuannya. Pembelajaran konvensional masih didasarkan atas asumsi bahwa pengetahuan dapat dipindahkan secara utuh dari pikiran guru ke pikiran siswa sehingga siswa tidak bisa mengembangkan proses belajarnya secara optimal.

Penggunaan metode pembelajaran yang bersifat pasif seperti metode ceramah atau metode konvensional kemungkinan besar akan memberikan pengaruh terhadap peningkatan hasil belajar siswa introvert, karena siswa introvert cenderung bersifat pasif dan lebih suka bekerja sendirian. Sedangkan penggunaan metode pembelajaran kooperatif akan memberikan pengaruh terhadap hasil belajar siswa extrovert, karena siswa extrovert cenderung bersifat aktif dan lebih kooperatif (suka bekerja sama dengan orang lain) (Ulya: 2016).

Metode konvensional dirasa kurang tepat jika diterapkan dalam Pembelajaran akuntansi, hal ini karena metode tersebut membuat siswa pasif dalam proses pembelajaran. Pembelajaran akuntansi merupakan salah satu dari pelajaran di SMA yang termasuk dalam ruang lingkup mata pelajaran ekonomi. Menurut Ahmadi dan Supriyono (2004) kesulitan belajar ditandai dengan hasil belajar yang rendah. Banyak siswa yang tidak menyadari bahwa konsep dalam pelajaran akuntansi tersusun secara berurutan. Artinya, jika siswa mengalami kesulitan dalam membahas materi, maka siswa akan kesulitan dalam memahami pada materi selanjutnya. Berdasarkan permasalahan yang telah di sampaikan tersebut, maka dibutuhkan metode yang tepat 
guna meningkatkan hasil belajar siswa. Salah satu metode yang perlu diuji cobakan dalam pembelajaran akuntansi adalah penerapan metode pembelajaran snowball throwing.

Metode snowball throwing menstimulus siswa untuk menyelesaikan masalah, komunikasi, penalaran, dan kepercayaan diri. Menurut Suprijono (2009) model pembelajaran snowball throwing adalah model pembelajaran yang memberikan pengalaman kepada siswa melalui pembelajaran terpadu dengan menggunakan proses yang saling berkaitan dalam situasi dan konteks komunikasi alamiah. baik sosial, sains, hitungan dan lingkungan pergaulan. Dibentuknya kelompok yang diwakili ketua kelompok untuk mendapatkan tugas dari guru kemudian masing masing siswa membuat pertanyaan yang dibentuk seperti bola (kertas pertanyaan) lalu dilempar ke siswa lain yang masing masing siswa menjawab pertanyaan dari yang diperoleh. Kelebihan dari model pembelajaran snowball throwing yaitu: mengungkapkan daya ingat, pembelajaran berpusat pada peserta didik, dan peserta didik aktif.

Kata snowball berasal dari bahasa Inggris yang berarti 'bola salju' dan throwing berarti 'melempar'. Jadi, snowball throwing berarti melempar bola salju. Pengertian bola salju dalam istilah metode snowball throwing bukan arti yang sebenarnya, namun istilah dari kertas yang diremas sehingga membentuk seperti bola salju. Selanjutnya kertas tersebut dilempar ke siswa lain. Metode snowball throwing merupakan salah satu dari modifikasi teknik bertanya yang dikemas dalam bentuk permainan sehingga siswa memiliki motivasi belajar yang lebih tinggi (Widodo: 2009)

Salah satu permasalahan serius yang sering terjadi dalam proses belajar adalah adanya perasaan ragu pada diri siswa untuk menyampaikan permasalahan yang dialaminya dalam memahami materi pelajaran. Guru sering mengalami kesulitan dalam menangani masalah ini. Tapi, melalui penerapan metod Snowball Throwing ini, siswa dapat menyampaikan pertanyaan atau permasalahannya dalam bentuk tertulis yang nantinya akan didiskusikan bersama, dengan demikian siswa dapat mengungkapkan kesulitan-kesulitan yang dialaminya dalam memahami materi pelajaran. Manfaat lain yang dapat diperoleh dengan menerapkan metode Snowball Throwing ini adalah, guru dapat melatih kesiapan siswa dalam menanggapi dan menyelesaikan masalah pembelajaran akuntansi (Sukertiasih : 2010).

Model pembelajaran snowball throwing secara filosofi merupakan salah satu jenis model pembelajaran cooperatif learning dimana dalam model pembelajaran ini terdapat kerjasama antar kelompok, saling ketergantungan antar siswa lainnya di dalam satu kelas. Model pembelajaran snowball throwing melatih siswa untuk lebih tanggap menerima pesan dari orang lain dan menyampaikan pesan tersebut kepada temannya dalam satu kelompok (Farhan, 2011).

Menurut Widodo (2009), metode snowball throwing merupakan gelundungan atau lemparan bola salju yang berisi pertanyaan dan selanjutnya dilemparkan oleh siswa kepada siswa lain, yang terkena lemparan wajib untuk menjawab pertanyaan yang tersedia di dalamnya. Selanjutnya dikatakan bahwa metode snowball throwing memiliki kelebihan dalam pelaksanaan pembelajaran yaitu : melatih kesiapan siswa dalam menerima pelajaran, saling memberikan pengetahuan antara siswa yang satu dengan siswa yang lainnya, adanya permainan, yaitu saling lempar-melempar pertanyaan antara siswa yang satu dengan siswa yang lainnya, dan menarik perhatian siswa mengenai materi yang dipelajari.

Metode pembelajaran snowball throwing sangat berbeda dengan metode pembelajaran konvensional yang dilakukan oleh guru di sekolah. Perbedaan ini terlihat dari sintaks dan metode yang digunakan dalam proses pembelajaran. Metode pembelajaran konvensional lebih cenderung guru yang aktif dalam proses 
pembelajaran, guru mentransfer begitu saja pengetahuan yang dimiliki kepada siswa tanpa memperhitungkan mental siswa (Rasana, 2009).

Perbandingan metode konvensional dan metode snowball throwing menurut Syukur, Muhardjito, dan Diantoro (2014) tampak pada tabel 1.

Tabel 1. Perbandingan metode konvensional dan metode snowball throwing

\begin{tabular}{l}
\hline \multicolumn{3}{c}{ Metode Konvensional } \\
\hline Pengajar sering membiarkan adanya \\
siswa saling mendominasi kelompok \\
atau menggantungkan diri pada \\
kelompok. \\
\hline Aktivitas individu sering diabaikan \\
sehingga tugas-tugas sering diborong \\
oleh salah seorang anggota kelompok.
\end{tabular}

Kelompok belajar cenderung homogen. Metode snowball throwing saling bantu dan saling memberikan motivasi sehingga ada interaksi positif. kelompok.

Aktivitas individu sering diabaikan Adanya akuntabilitas individual yang sehingga tugas-tugas sering diborong mengukur penguasaan materi pelajaran tiap anggota kelompok dan kelompok diberi umpan balik tentang hasil belajar para anggotanya sehingga saling mengetahui siapa yang memerlukan bantuan dan siapa yang membantu.

Kelompok belajar heterogen, baik dalam kemampuan akademik, jenis kelamin, ras, etnik.

Pimpinan kelompok sering ditentukan oleh pengajar atau kelompok dibiarkan untuk memilih pimpinannya dengan caranya masing-masing.

Pemantauan melalui observasi dan intervensi sering tidak dilakukan oleh pengajar pada saat belajar kelompok sedang berlangsung.

Pimpinan kelompok dipilih secara
demokratis atau bergilir untuk memberi pengalaman memimpin bagi para anggota kelompok.

Saat belajar kooperatif sedang berlangsung pengajar terus melakukan pemantauan melalui observasi dan melakukan intervensi jika terjadi masalah dalam kerja sama antar anggta kelompok.

Pengajar sering tidak memperhatikan Pengajar memperhatikan proses kelompok proses kelompok yang terjadi dalam yang terjadi dalam kelompok-kelompok kelompok kelompok belajar. belajar.

Penekanan hanya sering terjadi pada Penekanan tidak hanya pada penyelesaian penyelesaian tugas. tugas tetapi juga pada hubungan interpersonal (hubungan antar pribadi yang saling menghargai).

Berdasarkan penelitian terdahulu yang dilakukan oleh Rasyid dan Sumiati (2011) di Kelas X SMAN I Bajeng Kab. Gowa diperoleh hasil bahwa terdapat pengaruh positif pembelajaran snowball throwing terhadap hasil belajar siswa. Guru dan siswa memberi tanggapan positif terhadap model pembelajaran yang digunakan. Selain itu, terdapat penelitian serupa yang dilakukan oleh Januwardana, Siti, dan Putra (2014) di Kelas V SD Gugus 1 Kuta Badung diperoleh hasil bahwa terdapat perbedaan yang signifikan hasil belajar matematika antara siswa yang belajar melalui metode snowball throwing berbantuan media sederhana dengan siswa yang melalui pembelajaran konvensional.

Berdasarkan pendahuluan di atas, maka peneliti berniat membuktikan tentang: adanya perbedaan yang signifikan pada aspek hasil belajar siswa yang diajarkan dengan metode snowball throwing dan yang diajarkan dengan metode konvensional 
pada pembelajaran akuntansi kelas XI IPS SMAN Arjasa. Dugaan sementara peneliti yang kedua adalah hasil belajar siswa dalam pembelajaran dengan menggunakan metode snowball throwing lebih tinggi daripada hasil belajar siswa dengan menggunakan metode konvensional pada pembelajaran akuntansi kelas XI IPS SMAN Arjasa.

\section{METODE PENELITIAN}

Jenis penelitian ini merupakan penelitian eksperimen yang mengkaji perbedaan efektifitas pembelajaran akuntansi dengan metode snowball throwing dan metode konvensional pada materi akuntansi ditinjau dari hasil belajar siswa. Metode penentuan lokasi penelitian menggunakan metode purposive area. Lokasi penelitian adalah SMAN Arjasa. Penentuan responden penelitian menggunakan uji homogenitas pada siswa kelas IX IPS SMAN Arjasa untuk diambil 2 kelas yang homogen. Satu kelas sebagai kelas eksperimen yang diajar dengan menggunakan metode snowball throwing (XI IPS 1 SMAN Arjasa) dan kelas berikutnya sebagai kelas kontrol yang di ajar dengan menggunakan metode konvensional (XI IPS 3 SMAN Arjasa). Metode pengumpulan data yang digunakan terdiri dari metode tes, observasi, wawancara, dan dokumen. Jenis penyajian data yang digunakan adalah deskriptif kuantitatif.

Tes hasil belajar siswa digunakan sebanyak dua kali. Tes pertama bertujuan untuk mengetahui hasil belajar siswa kedua kelas sebelum perlakuan yang dilakukan pada pertemuan pertama dan tes kedua bertujuan untuk mengetahui hasil belajar siswa kedua kelas setelah perlakuan dan dilakukan pada pada pertemuan keempat. Banyaknya butir soal adalah sebanyak 15 soal. Tema soal yang digunakan dalam tes adalah perusahaan dagang dan jangka waktu penelitian adalah empat minggu atau empat kali pertemuan (empat kali pertemuan untuk kelas kontrol dan empat kali pertemuan untuk kelas eksperimen). Penelitian berlangsung pada tanggal 2 Februari 23 Februari 2017.

Jenis data dalam penelitian ini meliputi data primer dan data sekunder. Data primer yaitu data yang diperoleh secara langsung dari siswa XI IPS SMAN Arjasa dan data sekunder yang berupa dokumentasi diperoleh dari guru bidang studi.

Sumber data dalam penelitian ini diperoleh dari:

1. Responden yaitu siswa kelas XI IPS SMAN Arjasa

2. Informan yaitu guru mata pelajaran ekonomi akuntansi

3. Dokumentasi berupa nama siswa kelas XI IPS SMAN Arjasa dan jadwal pelajaran.

Desain penelitian tampak pada tabel di bawah ini :

Tabel 2. Desain penelitian

\begin{tabular}{lccc}
\hline \multicolumn{1}{c}{ Kelas } & Pretest & Treatment & Postest \\
\hline Eksperimen & $\mathrm{O}_{1}$ & $\mathrm{X}_{\mathrm{E}}$ & $\mathrm{O}_{2}$ \\
Kontrol & $\mathrm{O}_{3}$ & $\mathrm{X}_{\mathrm{K}}$ & $\mathrm{O}_{4}$ \\
\hline
\end{tabular}

Sumber : Sugiyono (2009)

Hasil penelitian dianalisis secara bertahap, yaitu: deskripsi data, uji normalitas data, uji homogenitas varians, uji beda (uji t). Uji normalitas data dimaksud untuk memperlihatkan bahwa sampel berasal dari populasi yang berdistribusi normal. Uji normalitas data pada aplikasi SPSS yaitu menggunakan uji statistic Kolmogorov-Smirnov dengan kriteria pengujiannya, yaitu: (a) Hipotesis $\mathrm{Nol}\left(\mathrm{H}_{0}\right)=$ data berdistribusi secara normal dengan probabilitas signifikansi $>0,05$, (b) Hipotesis Alternatif $\left(\mathrm{H}_{\mathrm{a}}\right)=$ data 
tidak berdistribusi secara normal dengan probabilitas signifikansi $<0,05$. Jika data berdistribusi normal maka uji hipotesis dapat dilakukan.

Uji normalitas data dilakukan pada kedua kelas data yaitu kelas eksperimen dan kelas kontrol. Selanjutnya yaitu melakukan uji beda (uji t). Tujuan uji t-test adalah membandingkan rata-rata dua kelas yang tidak berhubungan satu dengan yang lain. Jika kedua data dalam penelitian ini homogen dan berdistribusi secara normal maka dilakukan uji beda (uji t). Untuk uji beda (uji t) dengan SPSS dengan dua analisis yaitu pertama analisis varians atau homogenitas dan kedua adalah uji t-test.

\section{HASIL PENELITIAN DAN PEMBAHASAN}

Peneliti menganalisis hasil pretes dan postes pada kelas eksperimen (pembelajaran dengan menggunakan metode snowball throwing) dan kelas kontrol (pembelajaran dengan menggunakan metode konvensional). Berdasarkan hasil dari pretes, diketahui bahwa untuk kelas eksperimen diperoleh nilai 6,7 (tertinggi) dan 1,3 (terendah) dengan rata-rata 4,67 dan untuk kelas kontrol diperoleh nilai 9,3 dan 2,0 dengan rata-rata 5,42. Data hasil pretes tampak pada tabel 3.

Tabel 3. Data Hasil Pretes

\begin{tabular}{cccccc}
\hline Data & N & N. Max & N. Min & Rata-Rata & Standart Deviasi \\
\hline Eksperimen & 35 & 6.7 & 1.3 & 4.67 & 1.33 \\
Kontrol & 35 & 9.3 & 2.0 & 5.42 & 1.52 \\
\hline
\end{tabular}

Untuk membuktikan bahwa data hasil nilai pretes tersebar atau terdistribusi normal dan homogen, maka dilakukan pengujian dan hasilnya tampak pada tabel 4 dan 5. Tabel 4 dan 5 menunjukkan telah terpenuhinya syarat-syarat dilakukannya penelitian eksperimen (uji beda) dengan menggunakan kelas tersebut sebagai objek penelitian.

Tabel 4. Hasil Uji Distribusi Normal Pretes

\begin{tabular}{ccc}
\hline Kelas & Taraf Sig. & Ket \\
\hline Eksperimen & 0.15 & Distribusi Normal \\
Kontrol & 0.14 & Distribusi Normal \\
\hline
\end{tabular}

Tabel 5. Uji Homogenitas Varian

\begin{tabular}{cccc}
\hline Data & Df & P & Ket. \\
\hline Pretes & 68 & 0.403 & Homogen \\
\hline
\end{tabular}

Berdasarkan hasil dari postes, diketahui bahwa untuk kelas eksperimen diperoleh nilai 10,0 (tertinggi) dan 3,3 (terendah) dengan rata-rata 6,45. dan untuk kelas kontrol diperoleh nilai 9,3 dan 3,3 dengan rata-rata 5,56. Tabel data hasil postes tampak pada tabel 6.

Tabel 6. Data Hasil Postes

\begin{tabular}{cccccc}
\hline Data & N & N. Max & N. Min & Rata-Rata & Standart Deviasi \\
\hline Eksperimen & 35 & 10.0 & 3.3 & 6.45 & 1.55 \\
Kontrol & 35 & 9.3 & 3.3 & 5.56 & 1.55 \\
\hline
\end{tabular}

Kesimpulan yang diperoleh pada Tabel 6 adalah nilai pretes tertinggi dan terendah di kelas eksperimen masih di bawah kelas kontrol. Setelah adanya perlakuan, 
nilai tertinggi di kelas eksperimen melebihi nilai tertinggi kelas kontrol sedangkan nilai terendah di kelas eksperimen sama dengan nilai di kelas kontrol.

Selanjutnya peneliti melakukan uji beda hasil belajar pretes-postes kelas eksperimen. Pengujian ini dilakukan dengan cara menggunakan uji $t$, dan hasilnya tampak di tabel 7. Berdasarkan tabel 7, besarnya nilai $t_{\text {hitung }}=5.289>t_{\text {tabel }}=1.997$ sehingga Ho ditolak, sehingga terdapat perbedaan yang signifikan antara hasil dari pencapaian skor siswa di kelas eksperimen (pembelajaran dengan menggunakan metode snowball throwing) sebelum dilakukan tindakan dan setelah dilakukan tindakan (pretes-postes).

Tabel 7. Hasil T Test Skor Kelas Eksperimen

\begin{tabular}{ccc}
\hline$t_{\text {hitung }}$ & $\mathrm{df}$ & Sig. (2-tailed) \\
\hline 5.289 & 68 & 0.000 \\
\hline
\end{tabular}

Uji beda hasil belajar pretes-postes kelas kontrol juga dilakukan dengan uji t. Pengujian ini dilakukan dengan cara menggunakan uji $t$, dan hasilnya tampak pada tabel 8. Berdasarkan tabel 8 , besarnya nilai $t_{\text {hitung }}=0.382<t_{\text {tabel }}=1.998$ sehingga Ho diterima, sehingga tidak terdapat perbedaan yang signifikan antara hasil dari pencapaian skor siswa di kelas kontrol (pembelajaran dengan menggunakan metode konvensional) sebelum dilakukan tindakan dan setelah dilakukan tindakan (pretespostes).

\section{Tabel 8. Hasil T Test Skor Kelas Kontrol}

\begin{tabular}{lll}
\hline thitung & df & Sig. (2-tailed) \\
\hline 0.382 & 67 & 0.704 \\
\hline
\end{tabular}

Uji beda hasil belajar kelas eksperimen dan kelas kontrol dilakukan untuk membandingkan hasil belajar siswa pada kelas eksperimen (pembelajaran dengan menggunakan metode snowball throwing) dan kelas kontrol (pembelajaran dengan menggunakan metode konvensional). Hasil dari analisis uji t tampak pada tabel 9. Berdasarkan tabel 9, pada saat $\alpha=0.05 \mathrm{dan} \mathrm{df}=67, \mathrm{t}_{\text {hitung }}=2.385>\mathrm{t}_{\alpha / 2}=1.998$ maka Ho ditolak, artinya bahwa terdapat perbedaan yang signifikan pada hasil belajar siswa antara kelas eksperimen (pembelajaran dengan menggunakan metode snowball throwing) dan kelas kontrol (pembelajaran dengan menggunakan metode konvensional).

Tabel 9. Hasil T Test Skor Kelas Eksperimen dan Kelas Kontrol

\begin{tabular}{ccc}
\hline$t_{\text {hitung }}$ & $\mathrm{df}$ & Sig. (2-tailed) \\
\hline 2.385 & 67 & 0.020 \\
\hline
\end{tabular}

Hasil pretes menunjukkan bahwa nilai yang diperoleh siswa di kelas eksperimen sebesar 6,7 (tertinggi) dan 1,3 (terendah) dengan rata-rata 4,67 dan untuk kelas kontrol diperoleh nilai 9,3 dan 2,0 dengan rata-rata 5,42. Hal ini menunjukkan adanya perbedaan yang signifikan jika dilihat dari segi nilai tertinggi, ttetapi antara kelas eksperimen dan kelas kontrol keduanya masih mesih memiliki variansi yang homogen. Hal ini menunjukkan kelas tersebut memenuhi syarat untuk dijadikan objek penelitian.

Hasil postes menunjukkan bahwa nilai yang diperoleh siswa di kelas eksperimen sebesar 10,3 (tertinggi) dan 3,3 (terendah) dengan rata-rata 6,45 dan untuk kelas kontrol diperoleh nilai 9,3 dan 3,3 dengan rata-rata 5,56. Jika dibandingkan antara hasil 


\section{ASSEES JURNAL AKUNTANSI DAN PENDIDIKAN

pretes dan postes di kelas kontrol tidak terdapat perbedaan yang signifikan. Hal ini juga dibuktikan dari hasil analisis data (uji t). Sedangkan untuk kelas ekperimen jika dibandingkan antara hasil pretes dan postes terdapat perbedaan yang signifikan hal ini juga dibuktikan dari hasil analisis data (uji t). Sehingga dapat disimpulkan bahwa pembelajaran dengan menggunakan metode snowball throwing lebih berdampak pada hasil belajar siswa dari pada pembelajaran dengan menggunakan metode konvensional.

Kelas dengan metode pembelajaran snowball throwing (kelas eksperimen) siswa lebih aktif dalam mengolah pertanyaan dan jawaban. Pada tahap awal dalam menerapkan metode ini siswa masih mengalami kesulitan. Hal ini dikarenakan siswa sudah terbiasa dalam melakukan pembelajaran dengan menggunakan metode konvensional sehingga masih terkesan kaku dan siswa masih mengalami kebingungan dalam menerapkan tahapan-tahapan metode pembelajaran snowball throwing. Pertemuan kedua sampai pada pertemuan keempat, siswa mulai memahami tahapantahapan metode tersebut sehingga siswa sudah mulai aktif dan bahkan siswa mulai termotivasi dalam belajar dan senang hal ini karena ada permainan-permainan yang memancing siswa aktif hal ini terlihat dari antusiasme siswa dalam membuat pertanyaan dan berusaha mencari jawaban yang dilemparkan oleh siswa atau kelompok lain.

Hal ini sesuai dengan pernyataan Widodo (2009) yang menyatakan bahwa metode snowball throwing merupakan gelundungan atau lemparan bola salju yang berisi pertanyaan dan selanjutnya dilemparkan oleh siswa kepada siswa lain, yang terkena lemparan wajib untuk menjawab pertanyaan yang tersedia di dalamnya. Temuan di atas juga memperkuat hasil penelitian yang dilakukan oleh oleh Rasyid dan Sumiati (2011) bahwa terdapat pengaruh positif pembelajaran snowball throwing terhadap hasil belajar siswa. Guru dan siswa memberi tanggapan positif terhadap model pembelajaran yang digunakan. Disamping itu,terdapat penelitian serupa yang dilakukan oleh Januwardana, Siti, dan Putra (2014), diperoleh hasil bahwa terdapat perbedaan yang signifikan hasil belajar matematika antara siswa yang belajar melalui metode snowball throwing berbantuan media sederhana dengan siswa yang melalui pembelajaran konvensional

Kelas dengan metode pembelajaran konvensional (kelas kontrol) membuat siswa lebih tenang, duduk diam mendengarkan guru dalam memberikan materi hal ini terjadi karena guru mengendalikan jalannya proses pembelajaran dan siswa cenderung pasif. Hal semacam ini akan membuat siswa kurang termotivasi dalam belajar, terjadinya kebosanan dalam belajar, dan guru kurang memahami tingkat pemahaman siswa hal ini karena siswa yang telah paham dan belum paham cenderung diam, siswa yang belum paham tidak berani/ malu dalam bertanya kepada guru dan saat diberikan tugas oleh guru hanya sebagian saja yang mengerjakan secara tuntas.

Pernyataan di atas diperkuat oleh Rasana (2009) yang menyatakan bahwa pada metode pembelajaran konvensional, guru lebih cenderung aktif dalam proses pembelajaran, guru mentransfer begitu saja pengetahuan yang dimiliki kepada siswa tanpa memperhitungkan mental siswa. Hal ini sesuai dengan pernyataan Sanjaya (2011) yang menyatakan bahwa di dalam pembelajaran konvensional, siswa diposisikan sebagai objek dalam proses pembelajaran, berperan sebagai penerima informasi (pasif), mencatat dan menghafal materi-materi pembelajaran, disamping itu, menurut Ruseffendi (2005) dalam metode konvensional, guru diposisikan sebagai gudang ilmu, bertindak otoriter dan mendominasi di dalam kelas. Guru mengajarkan ilmu, guru langsung membuktikan dalil-dalil, guru membuktikan contoh-contoh soal. 
Sedangkan murid harus duduk mendengarkan, meniru pola yang diberikan oleh guru, mencontoh cara guru dalam menyelesaikan soal-soal. Murid bertindak pasif. Muridmurid yang kurang memahaminya terpaksa mendapat nilai kurang/jelek dan karena itu mungkin sebagian dari mereka tidak naik kelas.

\section{SIMPULAN}

Berdasarkan hasil dan pembahasan yang telah diuraikan, maka dapat disimpulkan hasil belajar di kelas eksperimen lebih tinggi daripada hasil belajar di kelas kontrol. Simpulan ini menjadi bahan pertimbangan guru dalam memilih metode yang sesuai dalam pembelajaran terutama metode snowball throwing, hal ini dimaksudkan untuk menstimulus siswa agar aktif dalam mengikuti pembelajaran. Pembelajaran snowball throwing tidak hanya digunakan untuk materi akuntansi saja, akan tetapi bisa pada materi lain yang berkaitan dengan situasi dan konteks komunikasi alamiah, baik sosial, sains, hitungan dan lingkungan pergaulan.

Keterbatasan dalam penelitian ini adalah : kesungguhan belajar siswa saat penelitian dilakukan merupakan hal yang berada di luar jangkauan peneliti untuk mengontrolnya, kesungguhan observer dalam mengamati aktivitas belajar siswa saat penelitian di luar jangkauan peneiti dalam mengontrolnya, sikap kepedulian dan keseriusan, serta objektivitas guru dan siswa dalam menjawab pertanyaan berada di luar jangkauan peneliti untuk mengontrolnya.

\section{DAFTAR PUSTAKA}

Ahmadi dan Supriyono. (2004). Psikologi Belajar. Jakarta: PT. Rineka Cipta. Arsyad, A. (2011). Media Pembelajaran. Jakarta: PT. Raja Grafindo Persada.

Farhan. (2011). Model Pembelajaran Kooperatif. Diakses pada 9 Desember 2011, dari http:// www.farhan-bjm.web.id/2011/09/ model-pembelajaran-kooperatif-tipe.

Januwardana, I. G. A., Zulaikha, S. dan Putra (2014). Pengaruh Metode Snowball Throwing Berbantuan Media Sederhana terhadap Hasil Belajar Matematika Siswa Kelas V SD Gugus 1 Kuta Badung. Jurnal Mimbar PGSD Universitas Pendidikan Ganesha Jurusan PGSD, 2, 1-12.

Lie, A. (2010). Cooperatif Learning, Mempraktekan Cooperatif Learning di Ruangruang Kelas. Jakarta: Grasindo.

Mulyasa, E. (2008). Standar Kompetensi dan Sertifikasi Guru. Bandung: PT Remaja Rosda Karya.

Rasana, I. D. P. R. (2009). Model - Model Pembelajaran. Singaraja: Universitas Pendidikan Ganesha.

Rasyid, M \& Sumiati. (2011). Pengaruh Penerapan Pembelajaran Snowball Throwing terhadap Hasil Belajar Siswa Kelas X SMAN I Bajeng Kab. Gowa (Studi pada Materi Pokok Senyawa Hidrokarbon). Jurnal Chemica, 12, 69 -76.

Ruseffendi, E. T. (2005). Dasar-dasar Matematika Modern dan Komputer untuk Guru Edisi 5. Bandung: Tarsito.

Sanjaya, W. (2011). Pembelajaran Dalam Implementasi Kurikulum Berbasis Kompetensi. Jakarta: Kencana.

Sugihartono, Kartika, H., dan Farida, S. (2007). Psikologi Pendidikan. Yogyakarta: UNY Press.

Sukertiasih, N. K. (2010). Implementasi Pembelajaran Kooperatif dengan Metode Snowball Throwing pada Pokok Bahasan Limit Fungsi untuk Meningkatkan Aktivitas dan Prestasi Belajar Siswa Kelas XI IPA SMA Saraswati Mataram Tahun Ajaran 2007/2008. GaneÇ Swara, 4, 69-78. 
Sukir. (2009). Metode Pembelajaran Inovatif. Diakses pada 27 November 2012, dari http://www. model.pembelajaran.html.

Suprijono, A. (2009). Cooperative Learning. Jakarta: Pustaka Pelajar.

Syukur, I. A., Muhardjito, dan Markus (2014). Pengaruh Model Pembelajaran Teams Games Tournament Termodifikasi Berbasis Outbound terhadap Prestasi Belajar Fisika Ditinjau dari Motivasi Belajar. Jurnal Pendidikan dan Kebudayaan, 20, 310-327.

Thoifuri. (2007). Menjadi Guru Insiator. Semarang: Rasail Media Group.

Ulya, N. M. (2016). Pengaruh Metode Pembelajaran dan Tipe Kepribadian Terhadap Hasil Belajar Bahasa Arab (Studi Eksperimen Pada MAN 1 Semarang). Nadwa Jurnal Pendidikan Islam, 10, 1-25.

Widodo, P. S. (2009). Meningkatkankan Motivasi Siswa Bertanya melalui Metode Snowball Throwing dalam Pembelajaran Pendidikan Kewarganegaraan. Jurnal Pendidikan Penabur, 8, 38 - 48.

Yuliati, L. 2008. Model-model Pembelajaran Fisika Teori dan Praktek. Malang: LP3 UM. 


\section{LAMPIRAN}

\section{PEDOMAN PENGUMPULAN DATA}

Observasi

\begin{tabular}{|c|c|c|}
\hline No & Data Yang Diperoleh & Sumber Data \\
\hline 1 & Mengamati dan menilai aktivitas belajar siswa & Siswa kelas XI SMAN Arjasa \\
\hline
\end{tabular}

Wawancara

\begin{tabular}{|c|c|c|}
\hline No & Data Yang Diperoleh & Sumber Data \\
\hline 1 & Metode pembelajaran yang biasa diterapkan & Guru Bidang Studi kelas XI \\
\hline & guru bidang studi ekonomi/akuntansi & IPS SMAN Arjasa \\
\hline 2 & Tanggapan guru bidang studi & Guru Bidang Studi kelas XI \\
\hline & ekonomi/akuntansi tentang metode snowball & IPS SMAN Arjasa \\
\hline & throwing & Guru Bidang Studi kelas XI \\
\hline 3 & Tanggapan guru bidang studi & IPS SMAN Arjasa \\
\hline & $\begin{array}{l}\text { ekonomi/akuntansi tentang hasil belajar siswa } \\
\text { sebelum dan sesudah treatment }\end{array}$ & Siswa kelas XI IPS SMAN \\
\hline 4 & $\begin{array}{l}\text { Tanggapan siswa tentang metode snowball } \\
\text { throwing }\end{array}$ & Arjasa \\
\hline 5 & $\begin{array}{l}\text { Tanggapan siswa tentang hasil belajar siswa } \\
\text { sebelum dan sesudah treatment }\end{array}$ & Arjasa \\
\hline
\end{tabular}

\section{Dokumentasi}

\begin{tabular}{|c|c|c|}
\hline No & Data Yang Diperoleh & Sumber Data \\
\hline 1 & $\begin{array}{l}\text { Daftar Presensi Siswa pada kelas XI IPS SMAN } \\
\text { Arjasa }\end{array}$ & $\begin{array}{l}\text { Guru Bidang Studi kelas XI } \\
\text { IPS SMAN Arjasa }\end{array}$ \\
\hline 2 & $\begin{array}{l}\text { Jadwal pelajaran siswa pada kelas XI IPS SMAN } \\
\text { Arjasa }\end{array}$ & $\begin{array}{l}\text { Guru Bidang Studi kelas XI } \\
\text { IPS SMAN Arjasa }\end{array}$ \\
\hline
\end{tabular}

Tes

\begin{tabular}{|c|l|l|}
\hline No & \multicolumn{1}{|c|}{ Data Yang Diperoleh } & \multicolumn{1}{c|}{ Sumber Data } \\
\hline 1 & Hasil belajar siswa & $\begin{array}{l}\text { Siswa kelas XI IPS SMAN } \\
\text { Arjasa }\end{array}$ \\
\hline
\end{tabular}

INSTRUMEN OBSERVASI PADA PROSES PEMBELAJARAN Lembar observasi pada kelas eksperimen

\begin{tabular}{|c|c|c|c|c|}
\hline \multirow{2}{*}{$\begin{array}{c}\text { Aktivitas yang } \\
\text { diamati }\end{array}$} & \multirow{2}{*}{ Kriteria Aktivitas } & \multicolumn{2}{|c|}{ Penilaian } & \multirow{2}{*}{$\begin{array}{c}\text { Jumlah } \\
\text { Siswa }\end{array}$} \\
\hline & & Aktif & Tidak & \\
\hline $\begin{array}{l}\text { Keterlibatan } \\
\text { dalam berdiskusi } \\
\text { dengan teman } \\
\text { kelompok }\end{array}$ & $\begin{array}{ll}\text { a. } & \text { Kelompok } 1 \\
\text { b. } & \text { Kelompok } 2 \\
\text { c. Kelompok } 3 \\
\text { d. Kelompok } 4 \\
\text { e. Kelompok } 5 \\
\text { f. Kelompok } 6 \\
\text { Tergolong aktif jika } \geq 4 \text { dari } 6 \text { kelompok } \\
\text { aktif dalam diskusi kelas. } \\
\text { Kriteria : (a - f) tergolong aktif jika 3-4 } \\
\text { siswa aktif melakukan diskusi dalam } \\
\text { kelompok }\end{array}$ & & & \\
\hline
\end{tabular}




\begin{tabular}{|l|l|l|l|l|}
\hline $\begin{array}{l}\text { Keterlibatan siswa } \\
\text { dalam } \\
\text { mengerjakan } \\
\text { tugas }\end{array}$ & $\begin{array}{l}\text { Tergolong aktif jika } \geq 20 \text { siswa telah } \\
\text { melaksanakan tugas dari guru dalam } \\
\text { membuat pertanyaan. }\end{array}$ & & & \\
\hline $\begin{array}{l}\text { Keterlibatan } \\
\text { dalam menjawab } \\
\text { pertanyaan }\end{array}$ & $\begin{array}{l}\text { Tergolong aktif jika } \geq 4 \text { siswa mengangkat } \\
\text { angan untuk menjawab pertanyaan dari } \\
\text { siswa lain. }\end{array}$ & $\begin{array}{l}\text { Tergolong aktif jika } \geq 20 \text { siswa menyimak } \\
\text { penjelasan guru selama proses } \\
\text { pembelajaran berlangsung. }\end{array}$ & & \\
\hline $\begin{array}{l}\text { Keterlibatan siswa } \\
\text { selama proses } \\
\text { pembelajaran. }\end{array}$ & & & \\
\hline
\end{tabular}

Lembar observasi pada kelas kontrol

\begin{tabular}{|c|c|c|c|c|}
\hline \multirow{2}{*}{$\begin{array}{l}\text { Aktivitas yang } \\
\text { diamati }\end{array}$} & \multirow{2}{*}{ Kriteria Aktivitas } & \multicolumn{2}{|c|}{ Penilaian } & \multirow{2}{*}{$\begin{array}{l}\text { Jumlah } \\
\text { Siswa }\end{array}$} \\
\hline & & Aktif & Tidak & \\
\hline $\begin{array}{l}\text { Keterlibatan siswa } \\
\text { dalam } \\
\text { memperhatikan } \\
\text { penjelasan guru }\end{array}$ & $\begin{array}{l}\text { Tergolong aktif jika } \geq 20 \text { siswa } \\
\text { mendengarkan penjelasan dari guru }\end{array}$ & & & \\
\hline $\begin{array}{l}\text { Keterlibatan siswa } \\
\text { dalam mencatat }\end{array}$ & $\begin{array}{l}\text { Tergolong aktif jika } \geq 20 \text { siswa } \\
\text { mencatat penjelasan dari guru }\end{array}$ & & & \\
\hline $\begin{array}{l}\text { Keterlibatan siswa } \\
\text { dalam bertanya }\end{array}$ & $\begin{array}{l}\text { Tergolong aktif jika } \geq 4 \text { siswa } \\
\text { mengangkat tangan untuk bertanya } \\
\text { pada saat guru memberi } 2 \text { kali } \\
\text { kesempatan bertanya. }\end{array}$ & & & \\
\hline $\begin{array}{l}\text { Keterlibatan siswa } \\
\text { dalam menjawab } \\
\text { pertanyaan }\end{array}$ & $\begin{array}{l}\text { Tergolong aktif jika } \geq 4 \text { siswa } \\
\text { mengangkat tangan untuk menjawab } \\
\text { pada saat guru memberi } 2 \text { kali } \\
\text { kesempatan menjawab. }\end{array}$ & & & \\
\hline $\begin{array}{l}\text { Keterlibatan siswa } \\
\text { dalam } \\
\text { menyimpulkan } \\
\text { materi. }\end{array}$ & $\begin{array}{l}\text { Tergolong aktif jika } \geq 20 \text { siswa } \\
\text { bersama-sama guru menyimpulkan } \\
\text { materi. }\end{array}$ & & & \\
\hline
\end{tabular}

\section{INSTRUMEN WAWANCARA}

\section{A. Wawancara dengan guru kelas}

1. Metode apa yang biasa digunakan dalam pembelajaran akuntansi di SMAN Arjasa?

2. Bagaimana sikap siswa terhadap metode yang biasa digunakan?

3. Bagaimana hasil belajar yang dicapai siswa dengan menggunakan metode yang biasa digunakan oleh Anda?

4. Kendala apa saja yang ditemui Anda selama proses pembelajaran?

5. Bagaimana tanggapan anda tentang metode snowball throwing?

6. Bagaimana tanggapan anda tentang hasil belajar siswa sebelum dan sesudah treatment?

7. Apa saran Anda terhadap penggunaan metode Snowball Throwing?

\section{B. Wawancara untuk siswa kelas VII}

1. Bagaimana pendapatmu tentang pelajaran akuntansi? 
2. Bagaimana pendapatmu tentang cara mengajar yang digunakan dalam pembelajaran selama ini?

3. Bagaimana pendapatmu mengenai penerapan metode snowball throwing dalam proses pembelajaran?

4. Bagaimana tanggapanmu tentang hasil belajar sebelum dan sesudah treatment?

\section{INSTRUMEN TES}

1. Pada awal tahun 2016 Nyonya Elza membuka usaha jasa salon dengan transaksi sebagai berikut :

Tanggal 9 januari dibeli peralatan salon senilai Rp. 40.000.000,00 baru dibayar sebesar Rp. 15.000.000,00 sisa akan dibayar kemudian.

Pencatatan mekanisme debit dan kredit yang benar adalah ...
A. Peralatan
Utang
Kas
Rp. 15.000.000,00 (D)
D. Peralatan
Rp. $40.000 .000,00$ (D)
Rp. 25.000.000,00 (D)
Utang
Rp. 15.000.000,00 (K)
Rp. 40.000.000,00 (K)
Kas
Rp. $25.000 .000,00(\mathrm{~K})$
B. Peralatan
Utang
Rp. 15.000.000,00 (D)
E. Peralatan
Rp. $25.000 .000,00$ (K)
Utang
Rp. 25.000.000,00 (D)
Rp. $40.000 .000,00$ (K)
Kas
Rp. 15.000.000,00 (D)
C. Peralatan
Utang
Rp. $40.000 .000,00$ (D)
Rp. $25.000 .000,00(\mathrm{~K})$
Kas
Rp. $15.000 .000,00(\mathrm{~K})$

2. Perhatikan data dua perusahaan berikut :

\begin{tabular}{|c|l|l|l|}
\hline \multirow{2}{*}{ No } & \multicolumn{2}{|c|}{ Keterangan } & \multicolumn{2}{|c|}{ Jumlah } \\
\cline { 3 - 4 } & & Perusahaan A & \multicolumn{1}{c|}{ Perusahaan B } \\
\hline 1. & Modal awal & Rp. $50.000 .000,00$ & Rp. $60.000 .000,00$ \\
2. & Modal akhir & Rp. $70.000 .000,00$ & Rp. 74.000.000,00 \\
3. & Beban gaji & Rp. $8.000 .000,00$ & Rp. $8.200 .000,00$ \\
4. & Beban bahan baku & Rp. $1.000 .000,00$ & Rp. $1.400 .000,00$ \\
5. & Beban utilitas & Rp. $300.000,00$ & Rp. 200.000,00 \\
\hline
\end{tabular}

Berdasarkan data di atas pada kedua perusahaan dapat disimpulkan ......
A. Pendapatan perusahaan A lebih kecil daripada perusahaan B
B. Pendapatan perusahaan A sama dengan perusahaan B
C. Pendapatan perusahaan A Rp. 20.000.000,00 dan perusahaan B Rp. 14.000.000,00
D. Pendapatan perusahaan A Rp. 29.000.000,00 dan perusahaan B Rp. 23.600.000,00
E. Pendapatan perusahaan A Rp. 29.300.000,00 dan perusahaan B Rp. 23.800.000,00

3. Data CV “Pandan" selama bulan Mei 2015 sebagai berikut :

$\begin{array}{ll}\text { - Pendapatan } & \text { Rp. } 50.000 .000,00 \\ \text { - Prive } & \text { Rp. } 1.000 .000,00 \\ \text { - Modal awal } & \text { Rp. } 65.000 .000,00 \\ \text { - Modal akhir } & \text { Rp. } 85.000 .000,00\end{array}$

Besar beban CV Pandan selama Mei 2015 adalah .......
A. Rp. $25.000 .000,00$
C. Rp. $30.000 .000,00$
E. Rp. $101.000 .000,00$
B. Rp. $29.000 .000,00$
D. Rp. $44.000 .000,00$ 


\section{ASSEIS JURNAL AKUNTANSI DAN PENDIDIKAN

4. Data sebagian PD "Permata" berikut ini :

- Penjualan

- Retur penjualan

- Potongan penjualan

- Pembelian

- Retur pembelian

- Potongan pembelian

- Beban angkut pembelian

- Persediaan barang dagang akhir

- HPP

Dari data diatas besar persediaan barang dagang awa adalc
A. Rp. $3.000 .000,00$
B. Rp. $4.000 .000,00$
C. Rp. $5.000 .000,00$
D. Rp. $6.500 .000,00$

Rp. $25.000 .000,00$

Rp. $1.000 .000,00$

Rp. $1.800 .000,00$

Rp. $11.000 .000,00$

Rp. $1.500 .000,00$

Rp. $1.000 .000,00$

Rp. $\quad 500.000,00$

Rp. $5.000 .000,00$

Rp. $9.000 .000,00$

5. Dari transaksi di bawah ini yang dicatat dalam jurnal jurnal penjualan adalah........

A. Dijual barang dagangan seharga Rp 800.000 .00 syarat 3/10, n/30

B. Dijual barang dagangan seharga Rp 1.000.000,00

C. Diterima pelunasan harga faktur yang telah dijual seharga $\mathrm{Rp} 1.000 .000,00$

D. Terjadi pengembalian barang dagangan karena cacat seharga Rp 200.000,00

E. Dijual barang dagangan seharga Rp 750.000,00. Diterima tunai Rp 400.000,00 sisanya bulan depan

6. Data CV “Pandan" selama bulan Mei 2015 sebagai berikut :
- Pendapatan
Rp. $46.000 .000,00$
- Prive
Rp. $1.000 .000,00$
- Modal awal
Rp. 65.000.000,00
- Modal akhir
Rp. 85.000.000,00

Besar beban CV Pandan selama Mei 2015 adalah
A. Rp. $25.000 .000,00$
C. Rp. $30.000 .000,00$
B. Rp. $29.000 .000,00$
D. Rp. $44.000 .000,00$
E. Rp. $101.000 .000,0$

7. Pada saat pernikahan putri pemilik catering $\mathrm{Bu}$ Djito semua pengeluaran pesta diambilkan dari kas milik perusahaan sebesar $\mathrm{Rp} 30.000 .000,00$ sedangkan kekurangan sebesar Rp 7.000.000,00 disumbangkan sendiri oleh pemilik catering. Hal ini dimasukkan pada persamaan akuntansi ....

A. kas berkurang $\operatorname{Rp} 37.000 .000,00$ dan modal berkurang $\operatorname{Rp} 37.000 .000,00$

B. kas berkurang Rp 30.000.000,00 dan modal berkurang Rp 30.000.000,00

C. kas berkurang Rp 30.000.000,00 dan modal berkurang Rp 23.000.000,00

D. kas berkurang Rp 30.000.000,00 dan modal berkurang Rp 7.000.000,00

E. kas berkurang Rp 23.000.000,00 dan modal berkurang Rp 7.000.000,00

8. Dibeli peralatan kantor seharga $\mathrm{Rp} 2.150 .000,00$ dari Toko Merbabu dan telah dibayar sebesar $\mathrm{Rp}$ 1.000.000,00 sisanya dibayar kemudian. Transaksi tersebut dicatat dalam jurnal yang benar adalah ....
A. Kas
$\operatorname{Rp} 1.000 .000,00$
Utang Usaha
$\operatorname{Rp} 1.150 .000,00$
Peralatan Kantor
Rp 2.150.000,00
B. Peralatan Kantor
$\operatorname{Rp} 1.150 .000,00$
Utang Usaha
Rp 1.000.000,00
Kas
Rp 2.150.000,00 

C. Kas
Utang Usaha
$\operatorname{Rp} 1.150 .000,00$
Rp 1.000.000,00
D. Peralatan Kantor Rp 2.150.000,00
Kas
Rp 1.150.000,00
Utang Usaha
E. Peralatan Kantor
Kas
$\operatorname{Rp} 1.100 .000,00$
Utang Usaha
Rp 2.150.000,00
Rp $1.000 .000,00$
Rp 1.150.000,00

9. Apabila terjadi transaksi berikut:
Kas
Rp 2.000.000,00
Pendapatan Komisi
Rp 3.000.000,00
Maka jurnal tersebut berasal dari transaksi..
A. dibayar utang komisi $\operatorname{Rp} 2.000 .000,00$
B. diterima pendapatan komisi Rp 2.000.000,00
C. dibayar tunai pendapatan komisi sebesar Rp 2.000.000,00
D. diterima piutang pendapatan komisi sebesar Rp 2.000.000,00
E. dibayar beban komisi kepada langganan sebesar Rp 2.000.000,00

10. Transaksi perusahaan dagang dan pencatatannya ke dalam jurnal khusus, yang benar adalah ....
A. membayar listrik, air dan telepon sebesar Rp 350.000,00 dicatat pada jurnal khusus penerimaan kas
B. penjualan barang dagang syarat 3/15, n/45 sebesar Rp 1.690.000,00 dicatat pada jurnal khusus penerimaan kas
C. penjualan perangkat computer secara tunai sebesar Rp 3.900.000,00 dicatat pada jurnal khusus penerimaan kas
D. pembelian barang dagang senilai Rp 3.000.000,00 dengan faktur no. 007 dicatat pada jurnal khusus pengeluaran kas
E. dibeli perlengkapan kantor sebesar Rp 700.000,00 dibayar dengan cek no. 66, dicatat pada jurnal khusus pembelian

11. Diketahui Modal Nona Permata pada 1 Januari 2011 sebesar Rp 66.000.000,00, selama tahun 2011 terjadi investasi tambahan sebesar Rp 4.000.000,00, prive Nona Permata Rp 7.000.000,00, pendapatan Rp 30.000.000,00 dan beban usaha Rp 19.000.000,00. Maka modal Nona Permata 31 Desember 2011 sebesar...
A. $\operatorname{Rp} 66.000 .000,00$
C. $\operatorname{Rp} 74.000 .000,00$
E. $\operatorname{Rp} 81.000 .000,00$
B. $\operatorname{Rp} 70.000 .000,00$
D. Rp $77.000 .000,00$

12. Sebuah perusahaan dagang mengerjakan pembukuan dimana sisi kredit pada akun utang dagang, terdapat jumlah sebesar Rp 7.000.000,00. Jumlah tersebut seharusnya dicatat pada ....
A. jurnal pembelian
D. jurnal pengeluaran kas
B. jurnal penjualan
E. jurnal penutup
C. jurnal penerimaan kas

13. Transaksi perusahaan dagang dan pencatatannya ke dalam jurnal khusus, yang benar adalah .... 


\section{ASSEIS JURNAL AKUNTANSI DAN PENDIDIKAN

A. membayar listrik, air dan telepon sebesar Rp 350.000,00 dicatat pada jurnal khusus penerimaan kas

B. penjualan barang dagang syarat 3/15, n/45 sebesar $R p 1.690 .000,00$ dicatat pada jurnal khusus penerimaan kas

C. penjualan perangkat computer secara tunai sebesar Rp 3.900.000,00 dicatat pada jurnal khusus penerimaan kas

D. pembelian barang dagang senilai Rp 3.000.000,00 dengan faktur no. 007 dicatat pada jurnal khusus pengeluaran kas

E. dibeli perlengkapan kantor sebesar Rp 700.000,00 dibayar dengan cek no. 66, dicatat pada jurnal khusus pembelian

14. Perhatikan matriks transaksi keuangan berikut:

\begin{tabular}{|c|l|l|l|}
\hline No & \multicolumn{1}{|c|}{ A } & \multicolumn{1}{c|}{ B } & \multicolumn{1}{c|}{ C } \\
\hline 1 & $\begin{array}{l}\text { Pembelian barang } \\
\text { secara tunai }\end{array}$ & $\begin{array}{l}\text { Menjual barang dengan } \\
\text { syarat 2/10,n/30 }\end{array}$ & $\begin{array}{l}\text { Menerima kembali } \\
\text { barang yang dijual } \\
\text { secara kredit }\end{array}$ \\
\hline 2 & $\begin{array}{l}\text { Pembelian barang } \\
\text { secara kredit }\end{array}$ & $\begin{array}{l}\text { Menjual barang dengan } \\
\text { menerima cek }\end{array}$ & $\begin{array}{l}\text { Mengirim kembali } \\
\text { barang yang dibeli } \\
\text { secara kredit }\end{array}$ \\
\hline
\end{tabular}

Transaksi yang dicatat ke dalam buku besar pembantu adalah ....
A. $\mathrm{A}_{1}, \mathrm{~B}_{1}$, dan $\mathrm{C}_{2}$
D. $\mathrm{B}_{1}, \mathrm{C}_{1}$, dan $\mathrm{C}_{2}$
B. $A_{1}, B_{2}$, dan $C_{1}$
E. $\mathrm{B}_{2}, \mathrm{C}_{1}$, dan $\mathrm{C}_{2}$
C. $\mathrm{A}_{2}, \mathrm{~B}_{1}$, dan $\mathrm{C}_{2}$

15. Transaksi usaha dagang Dua Putri bulan April 2011 antara lain:

01 Dibeli barang dagang dari UD Putro Mahardika senilai $\operatorname{Rp} 2.000 .000,00$

05 Dijual barang dagang kepada Nn. Rina senilai Rp 1.400.000,00 syarat pembayaran $2 / 10, \mathrm{n} / 30$

07 Dibeli barang dagang dengan tunai Rp 6.000.000,00

09 Dijual barang dagang kepada Nn Givna senilai Rp 1.800.000,00 diantaranya dibayar tunai sebesar Rp 1.400.000,00 sisanya dengan kredit

11 Diterima kembali barang yang dijual kepada Nn Givnia secara kredit karena rusak sebesar Rp 400.000,00

Dari transaksi tersebut, jumlah penjualan pada akun buku besar yang berasal dari posting jurnal penjualan sebesar ....
A. $\operatorname{Rp} 1.400 .000,00$
D. $\operatorname{Rp} 3.200 .000,00$
B. $\operatorname{Rp} 1.800 .000,00$
E. Rp 4.600.000,00
C. $\operatorname{Rp} 2.800 .000,00$ 